\title{
Instrument of Control And Accountability in Ebonyi State Local Government Councils, Nigeria
}

\author{
Uguru, Leonard C. Ph.D \\ Department of Accountancy, Ebonyi State University, Abakaliki, Nigeria
}

\begin{abstract}
The study examines the effect of instrument of control on public accountability in Ebonyi State Local Government Councils. The study adopted the cross-sectional survey design and administered questionnaire on 374 senior staff of the 13 Local Government Councils in Ebonyi State. The Binary Logit Regression technique was employed in the analysis of data. The result shows a significant effect of instrument of control on the public accountability in Ebonyi State Local Government Councils. The study hence recommends that cogent efforts should be made to review laws, rules and regulations concerning Local Government accounting and financial management. This will help in increasing the effectiveness of the instrument of controls in the Local Government Councils.
\end{abstract}

Keywords: Accountability, Control, Financial Memoranda, Local Government, Nigeria

\section{Introduction}

Local government is the closest tier of government to the people of Nigeria, yet the resident population in it is denied the benefits of its existence. The failure of local government in the area of service delivery over the years has made the citizens to lose faith and trust in local government administration as an institution in Nigeria (Oviasuyi, idada and Isiraojie, 2010). The essence of the creation of instruments of control like the constitution and the financial memorandum is to help in curbing corruptive tendencies at the local government councils. The Financial Memorandum is the foundation of local government administration. As the primary framework for the third tier financial management, it is the source and summit of governmental accounting in Nigeria local government system. Other instruments of control at the local government system are the Audit Act of 1956, Public Accounts Committee Act of 1987, Money Laundering Act of 1995, Corrupt Practices and Other Related Offences Act of 2000, Economic and Financial Crime Commission (Establishment) Act 2002 and others. However, Adebiyi (2002:177) observed that a good constitution does not guarantee good governance because "when human factors will not facilitate the optimum performance of a system, failure is inevitable". In spite of the apparently elaborate legal framework, the local government financial management is still not something to write home about likely due to corruption.

Audit constitutes the instrument of control in the financial and administrative process of operating government business. In recent years, however, the entire machinery for applying these control mechanisms by the Offices of the Auditor-General seems to have collapsed hence the confirmed financial improprieties in the local government areas in Nigeria (Udu, 2013). The duties of the Auditor-General are among others to audit and report on the public accounts of ministries and extra ministerial departments and other bodies created by an Act of the legislature.

The entire instruments of control in the local government seem to have collapsed. Consequently, there are increases in the mismanagement, scandalous embezzlement, extravagance, wastage, misappropriation, contract abandonment, overprizing of goods/service, salaries padding, capital flights and all other sorts of corruption (Udu, 2013). Thus the objective of the local government auditing seems to have been defeated owing to the widespread accusation by the public to the fact that auditors merely express true and fair view without attempting to conform to professional standards, legal requirement and other regulatory framework. Therefore, this study broadly aims to ascertain the effect of instrument of control on public accountability in Ebonyi State Local government Councils.

\section{Conceptual Review}

\subsection{Legal Instrument of Control in the Local Government Councils}

The business of government is always guided by laid-down rules, whether in form of policies, programmes, activities or functions. These rules and regulations are more rigorous particularly as it relates to the accounting and reporting for collecting and consumption of government finances that assist the process of good governance. The legal frameworks in the area of public sector accounting and financial management as contained in Oshisami (2004) include among others Acts, Circulars, rules, regulations, constitution and so on.

Anyafo (2002) states that government accounting in the country is anchored on a number of legal instruments that make up the statutory foundation upon which the public sector accounting manuals, treasury 
circulars, federal financial regulations, state financial instructions, and local government financial memorandum are established.

Table 1: Some of the Legal Instruments Regulating Local Governments

\begin{tabular}{|l|l|l|l|}
\hline Count & Description & Number & Year \\
\hline 1. & The Audit Act & No. 38 & 1956 \\
\hline 2. & The Financial (Control and Management) Act & No. 33 & 1958 \\
\hline 3. & The Financial (Control and Management) Amendment Act & No. 27 & 1987 \\
\hline 4. & Public Accounts Committee Act & No. 8 & 1987 \\
\hline 5. & The Civil Service (Re-organization) Act & No. 43 & 1988 \\
\hline 6. & The Civil Service (Re-organization) Amendment Act & No. 2 & 1991 \\
\hline 7. & Money Laundering Act & No. 3 & 1995 \\
\hline 8. & Advance Fee Fraud and Other Related Offences Act & No. 13 & 1995 \\
\hline 9. & Corrupt practices and other Related offences Act & No. 5 & 2000 \\
\hline 10. & Economic and Financial Crimes Commission (Establishment) Act & No. 5 & 2002 \\
\hline 11. & Corrupt Practices and Other Related Offences Act & No. 6 & 2003 \\
\hline 12. & Money Laundering (Prohibition) Act & No. 7 & 2003 \\
\hline 13. & Economic and Financial Crimes Commission (Establishment) Act & No. 1 & 2004 \\
\hline 14. & Monitoring of Revenue of Local Governments Act & No. 17 & 2005 \\
\hline 15. & Public Procurement Act & No. 32 & 2006 \\
\hline 16. & Due Process and Contract Certification Act & - & 2007 \\
\hline 17. & Investment and Securities Act & No. 29 & 2007 \\
\hline 18. & Fiscal Responsibility Act & No. 31 & 2007 \\
\hline 19. & Certain Political and Judicial Office Holders (Salaries and Allowances, etc) & No. 1 \\
\hline
\end{tabular}

Source: Anyafo (2004) and Achua (2009)

The Audit Act No. 38, 1956 has been reproduced as Chapter 17 of the Laws of the Federation of Nigeria and Lagos 1958 as amended by the Audit (Amendment) Ordinance No. 131960 and the Director of Audit (Change of Title) Decree No. 43, 1988 (Anyafo, 2002). As a supreme legal framework for public financial management, the 1999 Constitution of the Federal Republic of Nigeria is the prime documents and foundation of public sector accounting in Nigeria. The constitution encompasses key areas comprising the operations of finances that are widely acceptable as the pillar of public sector accounting; the other controls that are not internal for running the accounting system; and the budgetary process.

\subsection{Regulatory Framework for local Government Accounting}

The relevant sections of the 1999 constitution on powers and control (that is budgeting and auditing) over public funds at the federal and state levels as well as the public revenue allocation are Sections 80 to 88 , 120 to 128 and 162 to 168 respectively. However, the local government accounting is guided by the some regulatory instruments as provided in Oshisami (2004) and ICAN (2010).

(a) Nigerian Constitution: The 1999 Constitution of the Federal Republic of Nigeria is among the legal instruments that controls and dictate the revenue collection and payment procedures of public finances. It is the primary and supplement legal framework for accounting and financial reporting in government. The 1979 Constitution provided for the following very essential part in public sector accounting:

(i) How the funds are to be operated (which is widely agreed as the bedrock of accounting in the public sector),

(ii) Auditing and investigations as an instrument of controls for the operation of the accounting system.

(iii) The budgetary process.

(b) Financial Memorandum: The "Financial memorandum" (FM) as a legal framework in the third tier of government serves various purposes as an accounting and financial control instrument. Basically, it is a code of regulation. However, inclusive in other secondary though also vital purposes are that FM stands as a body of governing rules and includes a many technique or harmonization in the course keeping the records of some economic transactions and events. Viewing FM as a body of rules suggests that its positions in general are required to help in the accomplishment of transparency and accountability in the public sector (Oshisami 2004).

Parts of the financial memorandum comprise codes of regulations made up of rules which specify actions acceptable and those deemed unacceptable. These rules are not expected to be varied under any circumstances. Examples of these are the rules dealing with how to open a bank account with cheques, revenue collection, security of documents, and so on. The civil service being a complex and large organization requires set standards in order to ensure uniformity and conformity of application. There is also the need to develop effective means of communication in order to obviate costly errors. Like all large organizations, local government machinery requires rules which help safeguard its assets either from misuse or misappropriation. Hence it requires a code such as this to achieve its aims. 
Almost every chapter in the Financial Memorandum begins with definitions of the subject matter of the chapter. This is one way of avoiding misconception of the framework that is being laid down. To an undiscerning eye, thus might seem superfluous or even unnecessary but definitions go beyond providing meaning for terms used to delineating authority and scope of responsibilities, also give the nature of their responsibilities. More often than not, accounts officers and other managers who are responsible for effecting, operating or interpreting the provisions of the financial memorandum encounter situations of conflict when interpreting the spirit of its provisions. Sometimes such officers are accused of an inhuman approach to their work and back of initiative.

(c) Appropriation Acts: Appropriation Acts are made every year for the purpose, not just for controlling financial and accounting matters, but primarily to cater for issues such as finance as deemed fit for the recurrent expenditure. The bills passed into laws by the legislature are in two categories:

(i) Money bills, and

(ii) Other bills (being non-money bills).

A bill as defined in (a) above when passed is known as an Appropriation Act while the one as defined in subsection (b) is a Financial Act (Oshisami, 2004). Appropriation Acts regulate financial matters. They are also enacted each year principally for the appropriation of public moneys for services to be rendered during the year to which it applies.

(d) The Public Accounts Committee Act 1987 No. 8: This Act established the Public Accounts Committee to among other things examine the audited accounts of all ministries and extra ministerial departments and the Auditor-General for the Federation's report thereon. It is a committee of the legislature under sub-sections 85(5) and 125(5) of the 1999 Constitution.

(e) Treasury and Finance Circulars: They are extra administration instruments that are employed for the amendment or modification of the available provisions of financial regulations, civil service rules and the introduction of new policy guidelines.

(f) Finance (Control and Management) Act 1958: This Act governs the management and operation of all government funds. It regulates the accounting system, the books of accounts to be kept and the procedures to be followed in the preparation of accounts and financial statements. It also dictates the principles of valuation of government investment and which securities should form part of government's portfolio. The Act restricts the management of government fund investments to risk minimization and inhibits the Accountant-General of the Federation from pursuing the maximization of rate of return. Section 24 mandates the Accountant-General of the Federation to prepare, sign and present for audit the accounts showing fully the financial position on the last day of each financial year of the Consolidated Revenue Fund (CRF) and of the funds specified in the First Schedule.

\subsection{Budgeting in Local Government}

A budget is defined in ICAN (2010) as a statement expressed in monetary terms, produced and approved for a given period of time, usually one year, whose aim is to achieve a set goal. A budget is generally referred as annual estimates in the local government circles. For the fact that there is always shortage of available resources to satisfy the requirements or opportunities that the entity would like to seize, budgeting then becomes the best tool for both decision-making and resources allocation. The annual budgeting procedure can therefore be seen to be perhaps the simple most important decision and control routine from both the organizational and economic points of view. From an organizational perspective, the management is able to plan proper allocation of resources by employing the instrument of estimated revenues and expenditures.

Budgeting set out specific actions for the implementation of plans, programmes and projects by determining the level of resources needed to achieve specific plan objectives and setting out yearly allocations within the overall availability of annual revenue, while setting our performance criteria and control measures (Ugwoke and Onyeanu, 2013). At the budgeting stage of the financial management cycle, the constitution provides a broad framework for accountability carefully weaved around a budgeting process that involves principal public institutions and officers. For instance, Section $8(1)$ of the Constitution of the Federal Republic of Nigeria 1999 provides that the Chief Executive shall be responsible for the preparation and presentation to each house of the National Assembly / State House of Assembly, at any moment in time within the financial year, estimates of the revenue and expenditure of the federation for the next following financial year.

Budget discipline is the attunement of the budget procedure such that it produces an internally motivated control system. This involves the inculcation in budget operators, of timeliness of response to call circular and other vital information that may be required, the budget officers keeping to a predetermined 
calendar, and the executive keeping to overall budget ceilings as mandated by the legislature. In the opinion of Apampa and Oni (2009), there are no stipulations on how the public is to be provided with the information necessary to review budget performance at any level of government in Nigeria. They maintained that there is no legal framework that specifies the format for budget, the necessary documents that should be presented with the budget or how and when to disseminate budget information. In a similar manner, there is no statutory provision concerning the release of information on actual expenditure, purchases, public assets and liabilities. Also, the fiscal policy goal and plans included in the budget failed to include information on the government's intention on attainment of those plans.

In government, the budgetary or appropriation process derives the necessary authority from Funds and Accounts Laws; the Constitution of the Federal Republic of Nigeria, 1999, as amended in January 10, 2011; the relevant Decrees in vogue during the military regime; Local Government laws by various states of the Federation, and the Model Financial Memoranda for Local Governments, Chapter 2.

The Constitution provides for s system of Local Government by democratically elected councils under Section 7(1). To be rest assured of the existence and effective operation of the Local Government Areas, the constitution empower each state to enact enabling laws to provide for the establishment, structure, funds, and the operations of such Local Government Areas. The 1999 Constitution, as amended, specified the functions of Local Government Areas in its Fourth Schedule.

Consequent upon that provision, each State House of Assembly shall pass a bill on local governments of the State to cover the matters provided for in the constitution and submit to the Governor of the State for assent. It is a well known fact that majority of the states in the country, the Federal Capital Territory, Abuja inclusive and Ebonyi State, have passed their Local Government laws. The estimates prepared and laid before the state legislative arm by the state governor would no doubt include those of the Local Government Areas which would be incorporated by the controlling Ministry or Commission. It follows that Local Government Areas are governed through the State House of Assembly Legislation. However, Section 1 (2) of the Model Financial Memoranda for Local Government Areas set the guidance on the objectives of Draft Annual Estimates exercise.

Uchendu, Nwodialor and Obu (2014) cautioned that supplementary estimates should be used as a last resort as the frequency of its use is an apparent 'deficiency in the public finance system. It is discernible from above that the budgetary system appears perfect, but the fault in operation lies with those who execute the functions. Those individuals invested with the trust and faith of management of public resources must, of necessity, cultivate budgetary discipline.

\subsection{Audit of Local Government Account}

The 1999 Constitution does not recognize the office of the Auditor-General of the Local Governments of the State, unlike was the case under Section 123 of the still-born 1989 Constitution (Anyafo, 2002). Accordingly, the Auditor-General of each State of the Federation is required under the 1999 Constitution to take charge of the audit the third tier of government.

In the course of exercising these duties and functions as contained in the constitution, the AuditorGeneral should not be compelled to the directive or control of another recognized body or persons. Auditing is the last stage of the instruments of control with regards to financial accountability. Accountability will not be complete without effective auditing. In fact, auditing constitutes an inevitable control mechanism for ensuring proper management of economic resources and for ensuring compliance with prescribed financial policies and regulations in the local government. The financial memorandum provides for the major books of accounts to be kept by the local government treasuries. The auditor is duty bound to examine the books and accounts of the third tier of government to express an opinion whether the accounts give true and fair view of the operations and financial transactions of government.The entire instruments of control in the local government seem to have collapsed. Consequently, there are increases in the mismanagement, scandalous embezzlement, extravagance, wastage, misappropriation, contract abandonment, overprizing of goods/service, salaries padding, capital flights and all other sorts of corruption (Udu, 2013). Therefore, the objective of the local government auditing seems to have been defeated owing to the widespread accusation by the public to the fact that auditors merely express true and fair view without attempting to conform to professional standards, legal requirement and other regulatory framework. Unegbu and Kida (2011) state that the government auditor must satisfy himself that the books and account submitted were prepared in compliance with the statutory provisions and regulations as well as that good accounting principle and practice were followed in their preparation.

\section{Empirical Review}

Ademola (2003) carried out a study on the fund management and control in the state governments of Nigeria, using Ekiti State Government as the case organization, with the objective of finding out whether there is effective fund management and control of the state government fund. The study adopted the survey design 
using a 21 - item questionnaire. The sample size was 175 respondents drawn from the treasurers, accountants, cashiers and other fund managers in the state. The formulated hypotheses were tested using the Spearman's correlation method. The findings show that there is weak internal control over the state government funds which leads to ineffective fund management; that fund management positively correlated with the procedures and the state government performances.

Also, Emem (2008) carried out a study on public fund management and control in Nigeria using Boki Local Government as the case organization. A survey research design was adopted using 27 questions administered on 75 respondents. The result of the study revealed that the laid down procedures of fund administration are not strictly followed which leads to ineffective fund management in the public settings. Also, there is ineffective fund management caused by weak internal control system in the council as well as collaborations by the public fund administrators.

The study by Coker and Adams (2012) focused on how the third tier of government manage their funds upon the backdrops of the absence of financial autonomy, corrupt practices, and undue interferences in their affairs with basic emphasis in the manner and pattern of joint state-local government accounts are operated that allotted the state government the undeserved right over local government areas. With respect to the methodology, the paper employed the descriptive qualitative analysis technique. The findings revealed that local government areas in Nigeria have been underperforming as a result of the absence of financial autonomy, incessant interference of state governments in local government areas affairs, and so on. The study recommends for a full-fledged financial autonomy to be granted local government councils on issues that are constitutionally assigned to them; and the abrogation of the joint state - local government councils account system.

In another study by Onuorah and Appah (2012) on accountability and prudent financial management in Nigerian public sector, the control of public funds with respect to the manner of account rendition of public office holders as stewards was evaluated. Data was collected from Central Bank of Nigeria Statistical Bulletin for 48 years The findings show that the level of public accountability in Nigeria is not something to write home about due to the non-availability or partially available socio-economic and political information about the activities of government for the governed to assess the performance of their leaders. The study recommends that integrity, transparency and accountability in the management of public funds is of paramount importance if Nigeria is to move higher in the area growth and development. Also, accountability mechanisms and institutions of control need to be solidified to minimize the tempo of corruption in the country.

Uguru and Osuagwu (2012) assess the level of rural development in relation to funds made available to local government councils in Ebonyi State. Using the research instrumentation of questionnaire to collect primary data, the Z-test statistic was employed to test the 3 formulated statistical hypotheses, at $5 \%$ level of significance. The findings reveal that the level of infrastructural facilities in the rural communities in Ebonyi State is not commensurate with the available revenue to the local government councils. Also, audit alarms are never raised by the facilitators in the council against irregular or illegal payments by the Chairmen of the Councils. It then recommends that measures should be put in place to guard against fund mismanagement at the third tier of government to be rest assured of the provision of adequate and expected development to the rural communities through the appointment of external audit committees made up of reputable people of integrity from each local government council to monitor its finances and applicant.

The study by Coker and Adams (2012) focused on how the third tier of government manage their funds upon the backdrops of the absence of financial autonomy, corrupt practices, and undue interferences in their affairs with basic emphasis in the manner and pattern of joint state-local government accounts are operated that allotted the state government the undeserved right over local government areas. With respect to the methodology, the paper employed the descriptive qualitative analysis technique. The findings revealed that local government areas in Nigeria have been underperforming as a result of the absence of financial autonomy, incessant interference of state governments in local government areas affairs, and so on. The study recommends for a full-fledged financial autonomy to be granted local government councils on issues that are constitutionally assigned to them; and the abrogation of the joint state - local government councils account system.

Ugwoke and Onyeanu (2013) studied the problems in the principal instrument of control of public sector accounting and financial management in Nigeria. The paper aimed at determining the effectiveness and adequacy of the existing financial authorities. With a robust literature review, the primary data collected from 200 federal public/civil servants was used. The student $t$-test statistic at $5 \%$ level of significance was adopted as the suitable statistical tool to test the 2 formulated null hypotheses. The results indicate that the financial authorities are both ineffective and inadequate. It thus recommends that a substantial review of the existing laws, rules and regulations that guide public sector accounting and financial management be done; and a strengthening of the legal process not only to include very punitive sanctions but also to enforce same timely and exhaustively upon any infringement. Agba, Ocheni and Nnamani (2014) revisited the sources of local government funds and also examined the factors that affect the viability and buoyancy of local government areas as it relates to fiscal federalism in Nigeria. The paper employed the content analysis technique through 
review of related literature. The study observed some factors that affect local government fund management to include insufficient and below average performance in budgetary process, bad attitude towards work and lack of skilled manpower, administrative inefficiency, and quest for local government creation, among others. It then recommends that undue interference in the finances of local governments should reduce their grip of control and how they direct the LGAs to spend their funds through programmes and projects that are handed down to them.

Murana (2015) examines the sources of local government funds in Nigeria and evaluated the workable financing opportunities that are within the purview of local government areas in Nigeria. The study employed primary data through face-to-face interviews and observations. Using library research and content analysis, the study made the following findings: that the ideals of fiscal autonomy in the LGAs in Nigeria has been mortgaged; that structural and institutional problems have rendered the LGAs helpless on issues of revenue generation. It then recommends that mechanism should be put in place to promote transparency and accountability. Again, statutory allocation should be reviewed upward in favour of LGAs.

It was observed from all the empirical studies reviewed that there is need for the improvement of the ardency of the internal control over public funds in order to achieve the set objective for which they were created. While, Ugwoke and Onyeanu (2013) studied the problems in the principal instrument of control of public sector accounting and financial management in Nigeria, however, it was observed that none of the studies examined the effect of instrument of control on public accountability in Ebonyi State Local government Councils.

\section{Methodology}

The research design to be adopted in a research depends on the relevant discipline areas (Benbasat, Godlstein and Mead, 1987), the phenomenon being studied (Morgan and Smirchich, 1980; Benbasat and Zmud, 1999) and the feasibility of the research (Cooper and Schindler, 2003). Different research design exists but this study adopted the cross-sectional survey design. In this type of research design, observations are made at one or more points in time and a measuring scale called rating scale or checklist is used to record the observations made (Hassan, 1995, and ICAN, 2010). The cross-sectional design was adopted given the issues identified in the literature and considering the topic under study with regards to objective of the study. This is aimed at identifying variables and their relationship to one another. The study was mainly field study aimed at gathering the responses of the respondents from the Local Government Councils in Ebonyi State.

The population of the study consists of the senior staff of the Local Government Areas in Ebonyi state. The sample size of 374 staff of the 13 Local Government Councils in Ebonyi State was determined using Taro Yamane's formula. The instrument used for data collection in the study was a 5-point Likert scale questionnaire.

Hypothesis: There is no significant effect of instrument of control on the public accountability in Ebonyi State. The hypotheses were tested using the Binary Logit Regression with the Statistical Package for Social Sciences (SPSS) software at $5 \%$ level of significance.

\section{Results and Discussions}

Table 1: Logit Regression Result

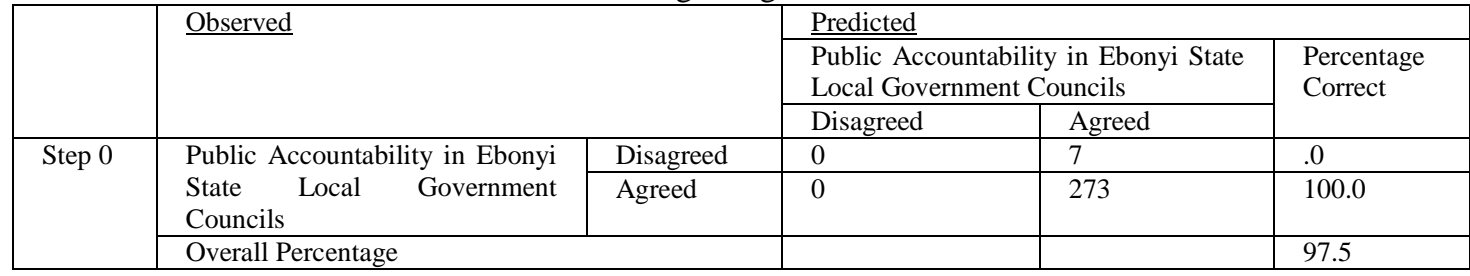

a. Constant is included in the model.

b. The cut value is .500

\begin{tabular}{|l|l|l|l|l|l|l|l|}
\hline \multicolumn{2}{|c|}{ Variables in the Equation } \\
\hline \multicolumn{2}{|l|}{} & B & S.E. & Wald & Df & Sig. & Exp(B) \\
\hline Step 0 & Constant & 3.664 & .383 & 91.603 & 1 & .000 & 39.000 \\
\hline
\end{tabular}

Source: Author's Binary Logit Regression Calculation

Table 2: Omnibus Tests of Model Coefficients

\begin{tabular}{|l|l|l|l|l|}
\hline \multicolumn{2}{|c|}{} & Chi-square & df & Sig. \\
\hline \multirow{3}{*}{ Step 1 } & Step & 20.537 & 10 & .025 \\
\cline { 2 - 5 } & Block & 20.537 & 10 & .025 \\
\cline { 2 - 5 } & Model & 20.537 & 10 & .025 \\
\hline
\end{tabular}

Source: Descriptive Statistics from Table 10 
The calculated value is 0.025 while the level of significance is 0.05 . Since the calculated value $(0.025)$ is less than level of significance (0.05), it means that the model is significant we then reject the null hypothesis and accept the alternative hypothesis. We therefore conclude that the independent variable predicts the dependent variable, that is, there is a significant effect of instrument of control on the public accountability in Ebonyi State Local Government Councils. The result was supported by the findings of previous studies such as Achua (2009); and Apampa \& Oni (2009).

\section{Conclusion and Recommendations}

It is a general belief that public accountability, which is simply the rendition of service and accounts to the public by people entrusted with public funds, cannot be possible where instrument of controls are not well enforced. The finding of the study reveals that instrument of control significantly affects public accountability in Ebonyi State Local Government Councils In view of the above, accountability is very necessary now especially in the face of lean resources available to Ebonyi state government and exacerbated by the high expectations of the citizens which have further imposed tremendous pressure on governments to ensure that they give the citizens minimum possible value for their money. The study hence recommends that cogent efforts should be made to review laws, rules and regulations concerning Local Government accounting and financial management. This will help in increasing the effectiveness of the instrument of controls in the Local Government councils.

[1]. Achua, J. K. (2009). Reinventing Governmental Accounting for Accountability Assurance in Nigeria. Nigeria Research Journal of Accountancy (NRJA), 1(1), $1-16$

[2]. Ademola, O. (2003). Empirical Study on Fund Management and Control: A Study of Ekiti State. An Unpublished M.Sc Dissertation in the Department of Accountancy, Ekiti State University, Ado-Ekiti. 83 P.

[3]. Anyafo, A. M. O. (2002). Public Sector Accounting. Enugu: GOPRO Foundation Publishers

[4]. Apampa, S.and Oni, T. (2009). Citizens: The Losers in a Weak Accountability System. Available online at http://www.chapter2.org.za/gboutputFiles.asp?writeContent =YERID=1078. Accessed on $17^{\text {th }}$ May, 2010.

[5]. Benbasat, I., Goldstein, D.K and Mead, M. (1987). The Case Research Strategy in Studies of

[6]. Information System. MIS Quarterly, 11(3), 369-386

[7]. Benbasat, I. and Zmud, R. W. (1999). Empirical Research in Information System: The Practice

[8]. of Relevance. MIS Quarterly, 23 (1), 3-18

[9]. Coker, M. A. and Adams, J. A. (2012). Challenges of Managing Local Government Finance in Nigeria. Research on Humanities and Social Sciences. 12(3), Available at (Online: http/www.iiste.org). Retrieved on 1/04/14.

[10]. Emem, A. (2008). Empirical Study on Local Government Fund Management and Control. Unpublished Thesis in the Department of Accountancy, University of Uyo, Uyo, Akwa Ibom State, 67 P.

[11]. ICAN (2010). Public Sector Accounting and Finance - Study Pack for PE II. Lagos: VI Publishers. 368 P.

[12]. Hassan, T. (1995). Understanding Research in Education. Lagos: Mayfield Publishing Company.

[13]. Morgan, G. and Smirchich, L. (1980). The Case of Qualitative Research. Academy of

[14]. Management Review, 5 (4) $419-500$.

[15]. Onuorah, A. C. and Appah, E. (2012). Accountability and Public Sector Financial Management in Nigeria. Arabian Journal of Business and Management Review, 1(6), 1 - 17.

[16]. Oviasuyi, P. O.; Idada, W. and Isijaorie, L. (2010). Constraints for Local Government Administration in Nigeria. Journal of Social Sciences, 24(2), $81-86$.

[17]. Uchendu, P. N.; Nwadialor, E. O. and Obu, G. N. (2014). Accounting and Financial management for Local Governments in Nigeria. Enugu: Optimal Publishers, 133P.

[18]. Udu, U. S. A. (2013). Financial Impropriety in Nigerian Governments: Restoring Confidence in Public Sector Auditing. Journal of Accounting and Contemporary Studies, 2 (1), 107 - 115.

[19]. Uguru, L. C. and Osuagwu, G. O. (2012). Financial Management of Local Government System and Rural Development in Ebonyi State. Salem Journal of Management Sciences, 1(2), 235 - 250.

[20]. Unegbu, A. O. and Kida, M. I. (2011). Effectiveness of Internal Audit as Instrument of Improving Public Sector Management. Journal of Emerging Trends in Economics and Management Sciences, 2(4), 304 - 309

[21]. Ugwoke, R. O. and Onyeanu, E. O. (2013). Inadequacies and Redundancies in the Principal Financial Authorities that guide public Sector Accounting and Financial Management in Nigeria. Research Journal of Finance and Accounting. 4(1), 16 - 25. 